University of Arkansas, Fayetteville

ScholarWorks@UARK

$2-5-2018$

\title{
Bigger Bang, Fewer Bucks? The Productivity of Public Charter Schools in Eight U.S. Cities
}

Corey A. DeAngelis

University of Arkansas, Fayetteville

Patrick J. Wolf

University of Arkansas, pwolf@uark.edu

Larry D. Maloney

University of Arkansas, Fayetteville

Jay F. May

University of Arkansas, Fayetteville

Follow this and additional works at: https://scholarworks.uark.edu/scdp

Part of the Education Policy Commons, Public Policy Commons, and the Social Policy Commons

\section{Citation}

DeAngelis, C. A., Wolf, P. J., Maloney, L. D., \& May, J. F. (2018). Bigger Bang, Fewer Bucks? The Productivity of Public Charter Schools in Eight U.S. Cities. School Choice Demonstration Project. Retrieved from https://scholarworks.uark.edu/scdp/2

This Report is brought to you for free and open access by the Education Reform at ScholarWorks@UARK. It has been accepted for inclusion in School Choice Demonstration Project by an authorized administrator of ScholarWorks@UARK. For more information, please contact scholar@uark.edu. 


\section{Bigger Bang, Fewer Bucks? The Productivity of Public Charter Schools in Eight U.S. Cities}

Corey A. DeAngelis

Patrick J. Wolf

Larry D. Maloney

Jay F. May

February 2018
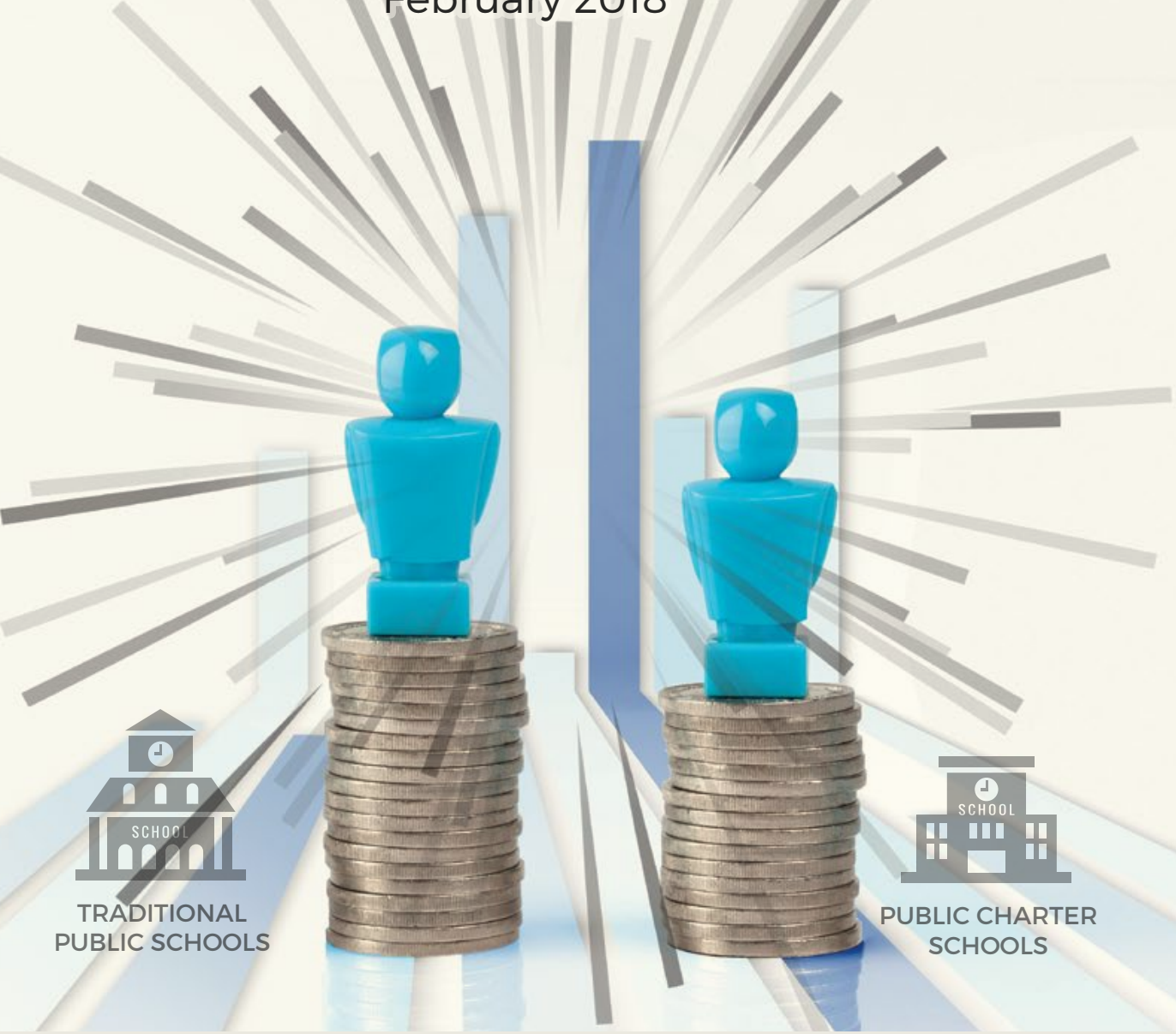

Atlanta • Boston • Denver • Houston • Indianapolis • New York City • San Antonio • Washington, D.C. 


\title{
Bigger Bang, Fewer Bucks? The Productivity of Public Charter Schools in Eight U.S. Cities
}

Corey A. DeAngelis

\author{
Patrick J. Wolf \\ Larry D. Maloney \\ Jay F. May
}

February 2018
School Choice Demonstration Project
Department of Education Reform University of Arkansas
201 Graduate Education Building Fayetteville, AR 72701

479-575-5475

http://www.uaedreform.org/bigger-bang-fewer-bucks-the-productivity-ofpublic-charter-schools-in-eight-u-s-cities/ 


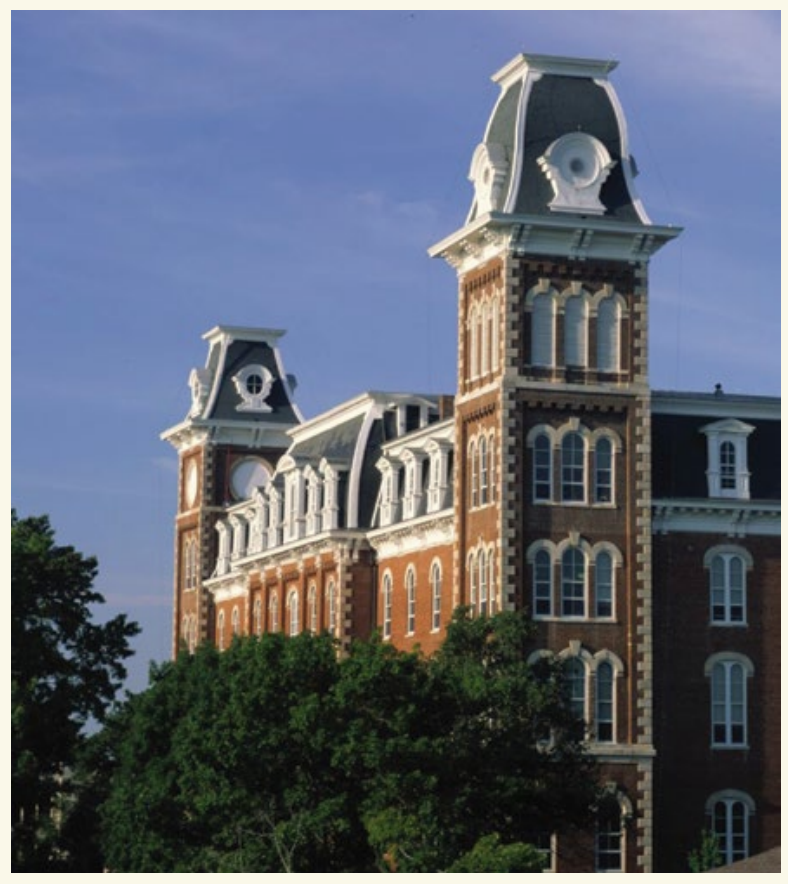

\section{The University of Arkansas}

was founded in 1871 as the flagship institution of higher education for the state of Arkansas. Established as a land grant university, its mandate was threefold: to teach students, conduct research, and perform service and outreach.

The College of Education and Health Professions established the Department of Education Reform in 2005. The department's mission is to advance education and economic development by focusing on the improvement of academic achievement in elementary and secondary schools. It conducts research and demonstration projects in five primary areas of reform: teacher quality, leadership, policy, accountability, and school choice.

The School Choice Demonstration Project (SCDP), based within the Department of Education Reform, is an education research center devoted to the non-partisan study of the effects of school choice policy and is staffed by leading school choice researchers and scholars. Led by Dr. Patrick J. Wolf, Distinguished Professor of Education Reform and Endowed 21st Century Chair in School Choice, SCDP's national team of researchers, institutional research partners and staff are devoted to the rigorous evaluation of school choice programs and other school improvement efforts across the country. The SCDP is committed to raising and advancing the public's understanding of the strengths and limitations of school choice policies and programs by conducting comprehensive research on what happens to students, families, schools and communities when more parents are allowed to choose their child's school. 
Bigger Bang, Fewer Bucks?

\section{The Productivity of Public Charter Schools in Eight U.S. Cities}

\section{Executive Summary}

In 2013-14, the United States spent over $\$ 630$ billion ${ }^{1}$ on its public education system in hopes of providing children with greater opportunities to excel academically and improve their life trajectories. While public education dollars have risen at a relatively fast pace historically, education policymakers and practitioners should be seeking to economize, given the uncertainties of future funding levels and underfunded pension liabilities. ${ }^{2}$ Meanwhile, the number of public charter schools has increased exponentially. From 1991 to 2014, charter school legislation passed in 42 states and the nation's capital, and student enrollment increased to around 2.7 million. ${ }^{3}$

Since educational resources are limited, it is imperative that we examine which types of schooling offer society the biggest "bang for the buck." Both cost-effectiveness and returnon-investment (ROI) analyses compare the productivity of different organizations that are providing a similar service - in this case, public education. Cost-effectiveness is "the efficacy of a program in achieving given intervention outcomes in relation to the program costs." ${ }^{4}$ Return-on-investment (ROI) is:

A performance measure used to evaluate the efficiency of an investment or to compare the efficiency of a number of different investments. ROI measures the amount of return on an investment relative to the investment's cost. To calculate ROI, the benefit (or return) of an investment is divided by the cost of the investment, and the result is expressed as a percentage or a ratio. ${ }^{5}$

In this report, we examine the differences in costeffectiveness and ROI for public charter schools and traditional public schools (TPS) in eight major cities in the United States. The cities are Atlanta,
Boston, Denver, Houston, Indianapolis, New York City, San Antonio, and the District of Columbia. We utilize data on how much money is invested in public charter schools and TPS, what levels of student achievement are attained across the two public school sectors, and how much economic payoff our society can expect to receive as a result of the educational investments in each sector. Ours is the first study to examine these differences across the United States at the city level.

We calculate the cost-effectiveness of the charter and TPS sectors in each city by taking the average National Assessment of Educational Progress (NAEP) scores achieved by each of them and dividing by their respective per-pupil revenue amount. Our cost-effectiveness measure is the amount of NAEP math and reading points generated from each $\$ 1,000$ in per-pupil revenue committed to each sector.

Our determination of the return-on-investment (ROI) in the public charter and TPS sectors requires additional data. We use information about the expected economic benefits accrued from spending 13 years ( $\mathrm{K}-12$ ) in each of the sectors to make that calculation. We also provide 
a hybrid ROI estimate based on a student spending 6.5 years in the charter sector and 6.5 years in the TPS sector. Since higher student achievement is associated with higher lifetime earnings, we are able to divide the cognitive impact of the K-12 educational experience by the cost-of-investment for each sector to calculate city-level ROIs. Finally, we provide cross-city and student-weighted averages for public charter and TPS cost-effectiveness and ROI based on our sample.

Overall, we find that public charter schools outperform TPS on both productivity metrics overall and for all eight cities. In particular, our cost-effectiveness analysis finds:

- In all eight cities, public charter schools outperform TPS in both math and reading cost-effectiveness;

- The public charter school sector delivers a cross-city average of an additional 4.34
NAEP points per $\$ 1,000$ funded in reading, representing a productivity advantage of 32 percent for charters, while the studentweighted public charter school advantage of 3.99 points per $\$ 1,000$ represents a costeffectiveness benefit of 35 percent;

- The public charter school sector delivers a cross-city average of an additional 4.73 NAEP points per $\$ 1,000$ funded in math, representing a productivity advantage of 33 percent for charters, while the studentweighted public charter school advantage of 4.37 points per $\$ 1,000$ represents a costeffectiveness benefit of 36 percent;

- The cost-effectiveness advantage for charters compared to TPS regarding NAEP reading scores ranges across the cities from 2 percent (Houston) to 67 percent (Washington, D.C.);

- The cost-effectiveness for charters compared to TPS in terms of NAEP math scores ranges from 2 percent (Houston) to 68 percent (Washington, D.C.).

\section{Figure ES 1: NAEP Points per $\$ 1,000$ of Funding in Public Charter Schools versus TPS, Cross-City Average}

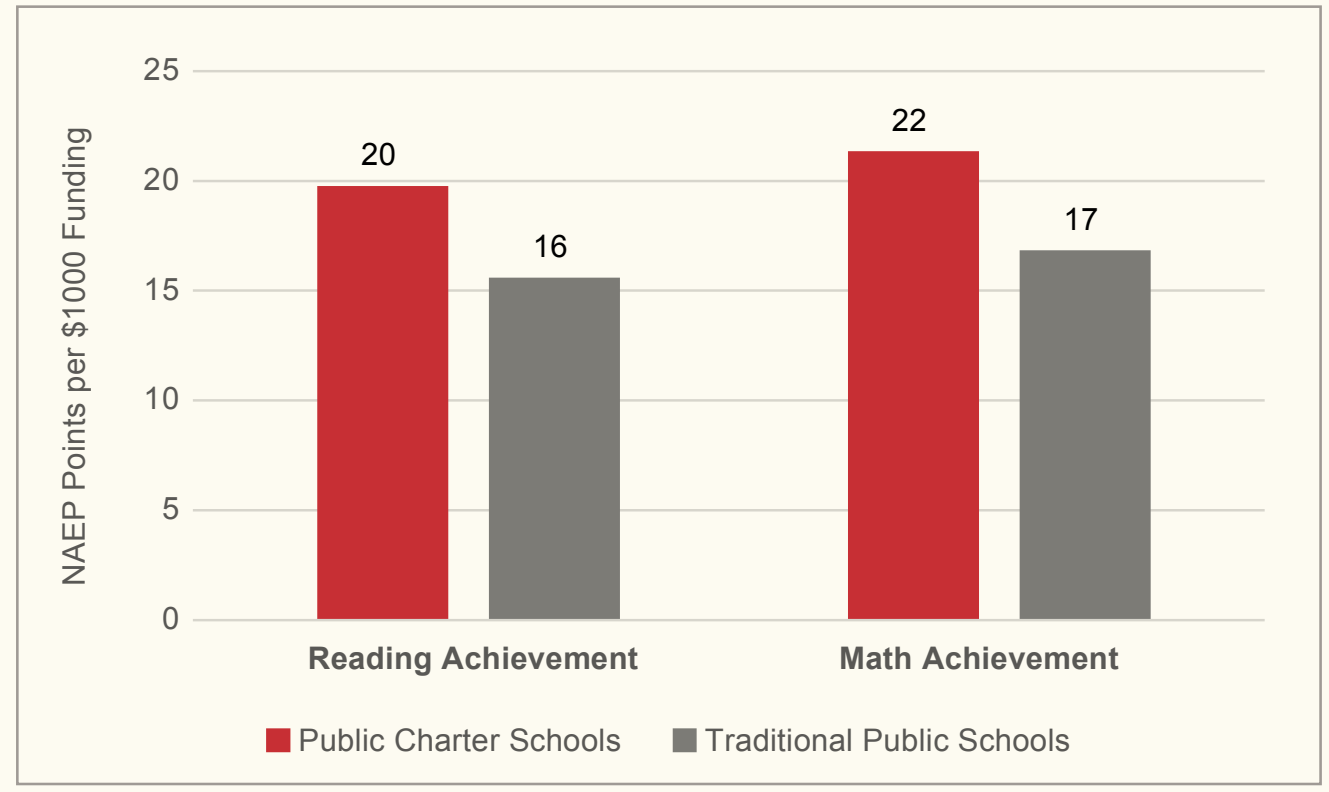

Note: Revenue data pertain to the 2014 Fiscal Year, which aligns with the 2013-2014 Academic Year, and are adapted from Charter School Funding: Inequity in the City, by Wolf et al., 2017, http://www.uaedreform.org/charter-school-funding-inequity-in-the-city/. NAEP achievement data are from 2015 and are adapted from http://nces.ed.gov/nationsreportcard/naepdata/dataset.aspx. 
Our return-on-investment (ROI) analysis finds:

- In all eight cities, public charter schools outperform TPS in standardized test scores despite receiving less funding per pupil;

- On average, each dollar invested in a child's K-12 schooling results in \$4.67 in lifetime earnings in TPS and \$6.44 in lifetime earnings in public charter schools, demonstrating a 38 percent public charter school advantage, while the student-weighted average charter school advantage in $\mathrm{ROI}$ is $\$ 2.09$ or 53 percent;

- Spending only half of the K-12 educational experience in public charter schools results in $\$ 5.40$ in benefits for each invested dollar, a 16 percent advantage relative to a full-time (13 year) $\mathrm{K}-12$ experience in TPS or 29 percent if student-weighted;

- The ROI advantage for an entire K-12 education in public charters compared to TPS ranges from 4 percent (Houston) to 85 percent (Washington, D.C.).
Figure ES 2: Additional Percentage ROI for Public Charter Schools Relative to TPS

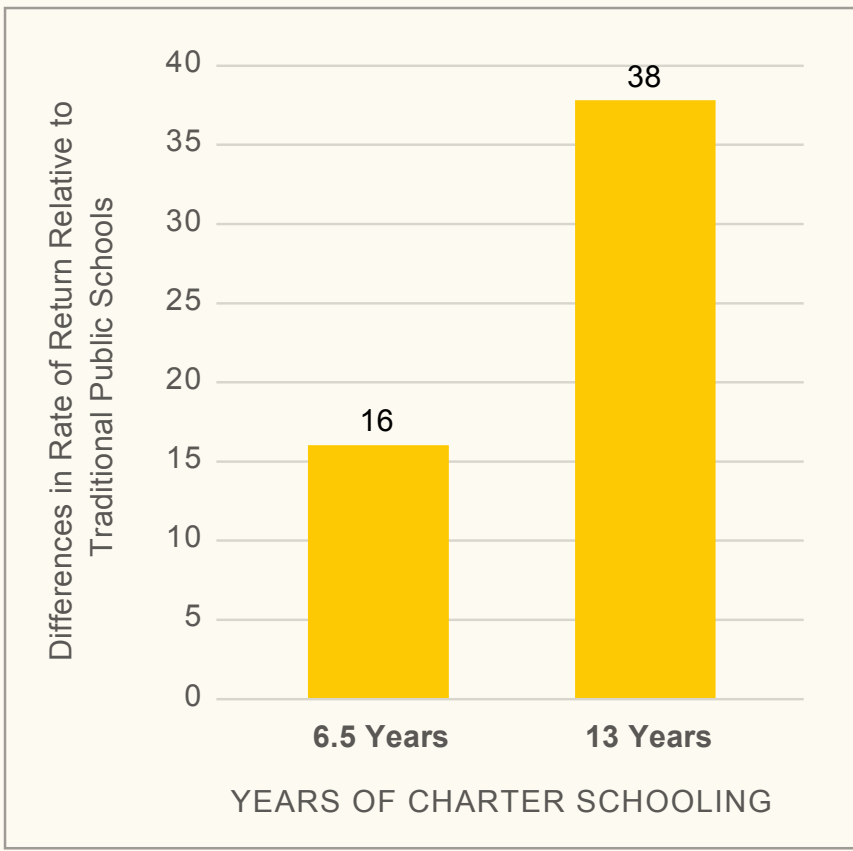

Note: Revenue data pertain to the 2014 Fiscal Year, which aligns with the 2013-2014 Academic Year, and are adapted from Charter School Funding: Inequity in the City, by Wolf et al., 2017, http://www.uaedreform.org/charter-school-fundinginequity-in-the-cityl. Achievement data are standardized relative to the state overall and cover 2006-07 to 2011-12 and are taken from the Center for Research on Education Outcomes (CREDO) Urban Charter School Study: Report on 41 Regions, http://urbancharters.stanford.edu/summary.php.

\section{Acknowledgements}

We thank Gary Larson, Jason Mandell and Molly O'Brien of Larson Communications for expert advice regarding the organization and clarity of this report. We are indebted to Albert Cheng for constructive comments on an early draft. We are grateful to Marlo Crandall of Remedy Creative for graphic design and formatting enhancements. We thank the Walton Family Foundation for the support that made this work possible and acknowledge that the content of the report is entirely the responsibility of the research team and does not necessarily reflect the positions of the Foundation or the University of Arkansas. 
Bigger Bang, Fewer Bucks?

The Productivity of Public Charter Schools in Eight U.S. Cities

\section{Introduction}

President Donald Trump called for a $\$ 20$ billion $^{6}$ reallocation of federal funds towards school choice programs during his campaign and appointed a strong supporter of school choice, Betsy DeVos, as U.S. Secretary of Education. These two events in particular have led to a robust discussion concerning the potential merits - and possible downsides - of choice programs.

School choice skeptics frequently claim that public charter schools perform no better than traditional public schools (TPS) on standardized test scores. ${ }^{7}$ Although a few individual studies of public charter schools have supported that claim, ${ }^{8}$ the most comprehensive research reports conclude that, though results vary across states and charter school networks, on average public charter schools have a positive effect on student achievement. ${ }^{9}$ Charter school performance appears to be especially strong in cities. ${ }^{10}$ Moreover, none of the studies of the relative effectiveness of public charter schools have explicitly considered the funding differences that exist across the two public school sectors. All of our research team's prior reports have found that students in public charter schools receive substantially fewer annual educational resources than their TPS peers. ${ }^{11}$ Private philanthropy does not compensate charters for the lack of equity in public funding because TPS receive it, too, and philanthropic dollars compose only 2.5 percent of total charter revenues nationally. ${ }^{12}$
Our team has produced the only prior study of the productivity of public charter schools, accounting for both their effectiveness and funding relative to TPS. ${ }^{13}$ Across our sample of 21 states plus the District of Columbia, we found that public charter schools generated 17 additional NAEP points in math and 16 additional points in reading per $\$ 1,000$ funded compared to TPS. We reported that the return-on-investment from a child spending half of their $\mathrm{K}-12$ experience ( 6.5 years)

\section{All of our research team's prior reports have found that students in public charter schools receive substantially fewer annual educational resources than their TPS peers.}

in a public charter school was 19 percent higher than from a child being educated exclusively in TPS.

Our previous public charter school productivity study compared charters to TPS at the state level. Most public charter schools open in cities, specifically to serve highly disadvantaged students. Do public charter schools demonstrate a productivity advantage in various cities across the U.S.? In this study, we aim to find out.

In our most recent school revenue study, our research team found that funding inequity has continued through the 2013-14 school year in 
Do public charter schools demonstrate a productivity advantage in various cities across the U.S.? In this study, we aim to find out.

12 out of 14 metropolitan areas examined in the U.S. ${ }^{14}$ Across the 14 locations, public charter schools received $\$ 5,721$ less per pupil than TPS, representing a funding inequity gap of 29 percent, on average.

In spite of the economic recovery, state and local governments remain concerned about their ability to finance public education. It is vital to determine where scarce educational resources should be allocated to maximize student success. Our current study builds upon our most recent charter funding inequity report by focusing on how taxpayer investments translate to student outcomes across the two public school systems. We are able to connect funding to student outcomes for a subset of eight of the 14 locations using revenue data from the fiscal 2014 school year. Cost-effectiveness is measured by how much $2015^{15}$ National Assessment of Educational Progress (NAEP) math and reading test score points each sector produced for each $\$ 1,000$ spent per student. Our second measure - ROI converts the learning gains experienced by public charter and TPS students to long-run economic

\section{Funding inequity has continued through the 2013-14 school year in 12 out of 14 metropolitan areas examined in the U.S.}

benefits, measured by expected impacts on lifetime earnings, and compares those benefits to the total revenues invested in each student's K-12 education.

We are able to connect funding to student outcomes for a subset of eight of the 14 locations previously examined - Atlanta, Boston, Denver, Houston, Indianapolis, New York City, San Antonio, and Washington, D.C.

previously examined - Atlanta, Boston, Denver, Houston, Indianapolis, New York City, San Antonio, and Washington, D.C.

We use two measures - cost-effectiveness and return-on-investment (ROI) - to determine which public school sector is producing the biggest bang for the taxpayers' bucks for those eight cities
We find that public charter schools outperform TPS in each of the eight cities on both productivity measures. On average across the cities, public charter schools are 31 to 32 percent more cost-effective and produce a 38 percent larger ROI than TPS. The charter cost-effectiveness advantage ranges from 2 percent in Houston to 68 percent in Washington, D.C., while the charter

We find that public charter schools outperform TPS in each of the eight cities on both productivity measures.

BIGGER BANG, FEWER BUCKS? THE PRODUCTIVITY OF PUBLIC CHARTER SCHOOLS IN EIGHT U.S. CITIES 
ROI advantage ranges from 4 percent in Houston to 85 percent in the nation's capital.

\section{Background: Spending and Achievement in the Eight Cities}

Scholars continue to debate the extent to which school resources affect student achievement. ${ }^{16}$ The eight cities in our sample vary substantially in both their average per-pupil funding for public school students in both the public charter and TPS sectors combined and student performance on the NAEP in reading relative to the average performance in each city's state (figure 1). Washington, D.C., funds the most per public-school pupil, an average of about $\$ 28,000$, and scores slightly above the state average on NAEP reading, which is difficult to interpret because D.C. is, in effect, its own state. ${ }^{17}$ San Antonio, in contrast, funds its public school students at a little over $\$ 11,000$ and its students score about equal to the Texas state average in reading on the NAEP, a rare achievement for a U.S. city. Denver commits slightly more revenue per TPS student than San Antonio, but its TPS student NAEP scores in reading are more than 50 percent below the Colorado state average.

Although the relationship between per-pupil funding and student performance relative to state averages is statistically zero for these cities, places like New York City may commit so much revenue to public education precisely because they have a student body that is more difficult to educate, leading to low student outcomes even with a high commitment of resources. Obviously, comparing differences in revenue and outcomes across cities is not a strong method for determining how educational resources actually affect student achievement, and we present these figures merely to illustrate the spending and achievement backgrounds of our cities.

\section{Figure 1: Relationship between Revenue and Achievement by City in the Sample}

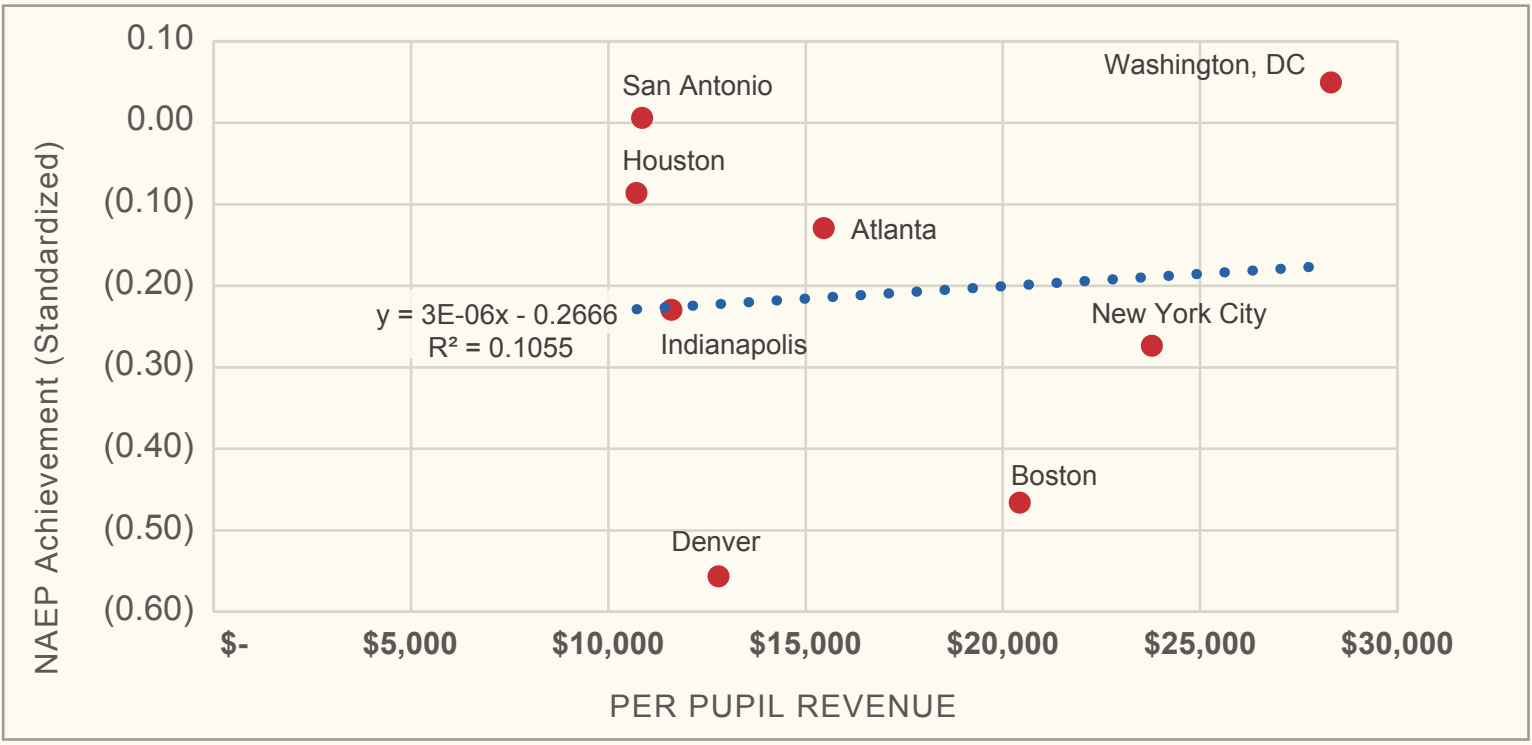

Note: Revenue data pertain to the 2014 Fiscal Year, which aligns with the 2013-2014 Academic Year, and are adapted from Charter School Funding: Inequity in the City, by Wolf et al., 2017, http://www.uaedreform.org/charter-school-funding-inequity-in-the-city/. Achievement data are standardized relative to the state overall and cover 2006-07 to 2011-12 and are provided by the Center for Research on Education Outcomes (CREDO) Urban Charter School Study: Report on 41 Regions, http://urbancharters.stanford. edu/summary.php.

BIGGER BANG, FEWER BUCKS? THE PRODUCTIVITY OF PUBLIC CHARTER SCHOOLS IN EIGHT U.S. CITIES 
As an improvement upon the descriptive data illustrated above, we compare NAEP scores to per-pupil funding across public school sectors within the same city. This way we control for cross-city differences in student

backgrounds in our analyses.

We present two averages of the results across the cities in our sample. The first is the average of the cities, treating each city as a single, equallyweighted observation. The second is a studentweighted average across the sample, which gives greater weight to cities that have more students contributing to the calculation and less weight to cities that have fewer students contributing. The student-weighted calculations of costeffectiveness and $\mathrm{ROI}$ are completed in two steps. First, we determine the weighted-student averages separately by public school sector, with cities with relatively larger TPS sectors weighted more heavily in the TPS calculation and cities with relatively larger public charter sectors weighted more heavily in the charter calculation. After the student-weighted average results are determined for each sector, the lower number (always the TPS number in our case) is subtracted from the higher number (always the public charter number in our case) to determine the weighted average of the charter productivity advantage (see the Methodology Appendix for details). This twostep process generates true student-weighted average productivity levels across our sample at both the sector and overall levels. If, instead, one weights each city's results by the combined K-12 student population for both TPS and charter, the productivity results change somewhat but not dramatically. 
students labeled as English learners or in special education, but those enrollment gaps failed to explain much of the revenue differences between the public school sectors in Denver, Indianapolis, New York City, San Antonio, or Washington. Thus, different levels of student disadvantage across the public school sectors in our cities explain some but not all of the productivity advantage for public charter schools.

\section{Cost-Effectiveness Using NAEP Achievement Scores}

Cost-effectiveness is "the efficacy of a program in achieving given intervention outcomes in relation to the program costs." ${ }^{20}$ Our study measures the effectiveness of the school system to attain outcomes relative to the costs associated with improving children's academic achievement throughout their 13-year K-12 educational experience. We use the nation's report card - NAEP math and reading scores - as the intervention outcome and the total perpupil revenue allocated in fiscal year (FY) 2014 to students in the public charter and TPS sectors as the program cost.

Students in $4^{\text {th }}, 8^{\text {th }}$, and $12^{\text {th }}$ grade take the NAEP exam. The $4^{\text {th }}$ grade NAEP results likely understate all of the learning acquired throughout the K-12 educational experience, as students still have over 60 percent of their schooling remaining. The $12^{\text {th }}$ grade NAEP results likely overstate overall learning levels because they do not include struggling students who dropped out prior to $12^{\text {th }}$ grade. As a result, we use $8^{\text {th }}$ grade NAEP math and reading test scores for our outcome in this analysis. The results are similar if $4^{\text {th }}$ grade NAEP scores are used in place of $8^{\text {th }}$ grade scores, and $12^{\text {th }}$ grade
NAEP scores are not available at the individual city level. Although it would be interesting to compare the cost-effectiveness of the public charter and TPS sectors specifically for lowincome students, such subgroup NAEP data are not available at the city level.

Math and reading scores are not the only outcomes produced by educational institutions. However, public schools explicitly focus on standardized tests, especially since math and reading test scores were public school accountability measures mandated by the federal government during the period of this study. Further, math and reading test scores at the very least serve as a proxy measure for the overall quality of Math and reading test scores at the very least serve as a proxy measure for the overall quality of an educational experience. an educational experience. Our first measure is calculated as:

$$
\text { Cost-Effectiveness }=\frac{\text { Achievement Scores }}{\text { Per-Pupil Revenue }}
$$

See the sidebar for an example computation of cost-effectiveness for Atlanta. After considering the per-pupil funding differences across the two sectors, Atlanta public charter schools produced an average of 2.16 more points on the NAEP reading assessment and 2.26 more points on the NAEP math exam for each $\$ 1,000$ in funding than Atlanta TPS. This difference illustrates a 14 percent public charter school advantage over TPS in cost-effectiveness in producing reading and math scores. 


\section{Atlanta public charter schools produced an average of 2.16 more}

\section{points on the NAEP reading assessment and 2.26 more points on} the NAEP math exam for each \$1,000 in funding than Atlanta TPS.

\section{Overall Cost-Effectiveness Results}

Now we consider the results across all eight of our cities.

The average public charter school sector in our sample produced 17.76 NAEP reading points per $\$ 1,000$ funded compared to 13.42 points in the average TPS sector (table 1). This 4.34 NAEP reading score difference represents a 32 percent public charter school sector advantage over TPS in cost-effectiveness. Accounting for the different sizes of the K-12 populations in the public charter and TPS sectors of the eight cities, the studentweighted average production of the public charter sector was 15.28 NAEP reading points per \$1,000 compared to 11.29 for TPS. The studentweighted public charter school advantage of 3.99 points per $\$ 1,000$ represents a cost-effectiveness benefit of 35 percent.

\section{Example Computation: Atlanta}

Our cost-effectiveness metric is a benefit-cost ratio of NAEP math and reading achievement to average per-pupil revenues allocated for each sector. This calculation can be expressed as:

$$
\text { Cost-Effectiveness }=\frac{\text { NAEP Achievement Points }}{\text { Per-Pupil Revenue }}
$$

In Atlanta traditional public schools, average NAEP scores were 257 for reading and 272 for math, and per-pupil revenue was \$16,429. In Atlanta public charter schools, average NAEP scores were 258 points for reading and 273 for math, and per-pupil revenue was $\$ 14,490$. Notably, even if funding levels were equal across the two public school sectors, public charter schools in Atlanta would be more cost-effective than TPS in 2014, as they produced higher math and reading test scores.

The cost-effectiveness calculations for Atlanta are the following:

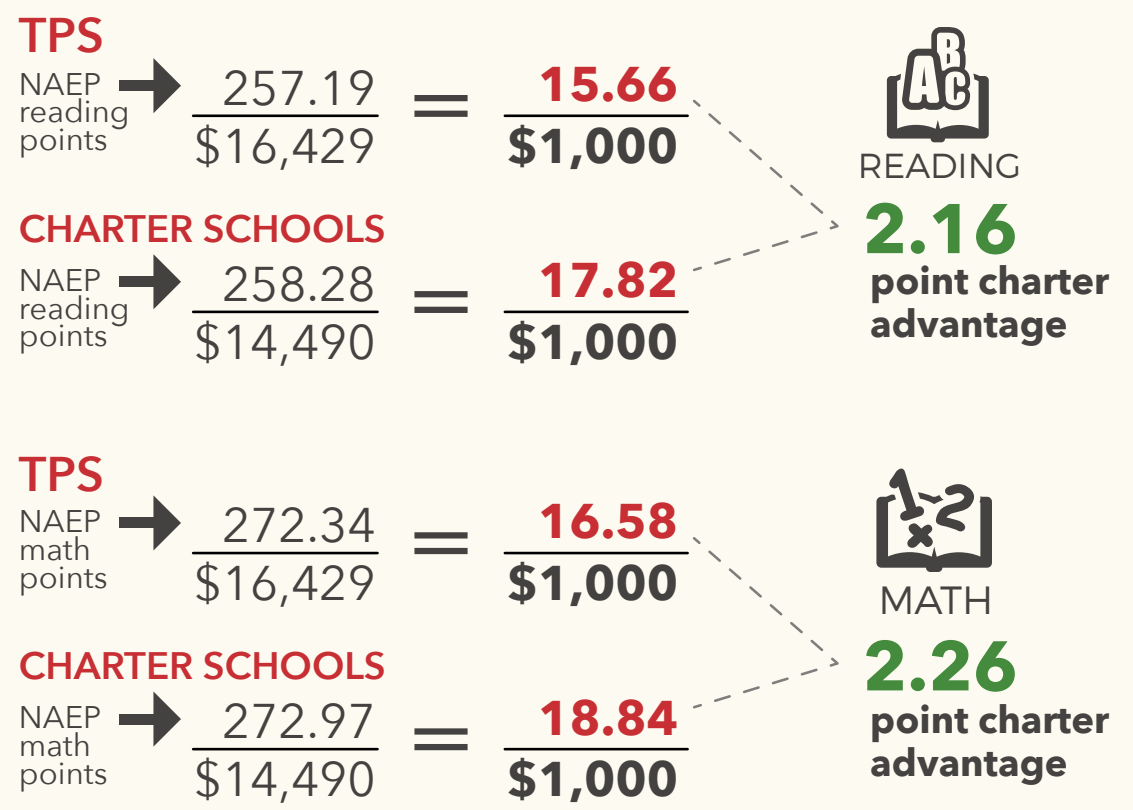


This 4.34 NAEP reading score difference represents a 32 percent public charter school sector advantage over TPS in cost-effectiveness.

Table 1: NAEP Reading Achievement Levels per Thousand Dollars Funded

\begin{tabular}{|l|r|r|r|r|r|r|r|}
\cline { 2 - 9 } \multicolumn{1}{c|}{} & \multicolumn{3}{|c|}{ Traditional Public Schools } & \multicolumn{2}{c|}{ Public Charter Schools } & Difference \\
\hline Location & $\begin{array}{c}\text { NAEP } \\
\text { Score }\end{array}$ & $\begin{array}{l}\text { Per Pupil } \\
\text { Revenue }\end{array}$ & $\begin{array}{c}\text { NAEP Points } \\
\text { per } \$ 1,000 \\
\text { Funded }\end{array}$ & $\begin{array}{c}\text { NAEP } \\
\text { Score }\end{array}$ & $\begin{array}{c}\text { Per Pupil } \\
\text { Revenue }\end{array}$ & $\begin{array}{c}\text { NAEP Points } \\
\text { per } \$ 1,000 \\
\text { Funded }\end{array}$ & $\begin{array}{c}\text { NAEP Points } \\
\text { per } \$ 1,000 \\
\text { Funded }\end{array}$ \\
\hline Indianapolis & 258.77 & $\$ 14,388$ & 17.99 & 261.46 & $\$ 8,810$ & 29.68 & 11.69 \\
\hline San Antonio & 260.34 & $\$ 12,097$ & 21.52 & 261.46 & $\$ 9,629$ & 27.15 & 5.63 \\
\hline Denver & 247.95 & $\$ 14,027$ & 17.68 & 249.21 & $\$ 11,083$ & 22.49 & 4.81 \\
\hline Washington, D.C. & 247.72 & $\$ 35,261$ & 7.03 & 251.12 & $\$ 21,387$ & 11.74 & 4.71 \\
\hline Boston & 253.95 & $\$ 22,389$ & 11.34 & 262.21 & $\$ 18,475$ & 14.19 & 2.85 \\
\hline New York City & 253.10 & $\$ 26,289$ & 9.63 & 254.25 & $\$ 21,281$ & 11.95 & 2.32 \\
\hline Atlanta & 257.19 & $\$ 16,429$ & 15.66 & 258.28 & $\$ 14,490$ & 17.82 & 2.17 \\
\hline Houston & 257.40 & $\$ 10,829$ & 23.77 & 258.03 & $\$ 10,604$ & 24.33 & 0.56 \\
\hline CITY AVERAGE & 254.55 & $\$ 18,963$ & 13.42 & 257.00 & $\$ 14,470$ & 17.76 & 4.34 \\
\hline STUDENT-WEIGHTED & 253.84 & $\$ 22,480$ & 11.29 & 255.48 & $\$ 16,718$ & 15.28 & 3.99 \\
\hline AVERAGE & & & & & & & \\
\hline
\end{tabular}

Note: Revenue data pertain to the 2014 Fiscal Year, which aligns with the 2013-2014 Academic Year, and are adapted from Charter School Funding: Inequity in the City, by Wolf et al., 2017, http://www.uaedreform.org/charter-school-funding-inequityin-the-city/. NAEP achievement data are from 2015 and are adapted from http://nces.ed.gov/nationsreportcard/naepdata/ dataset.aspx.

These cost-effectiveness results differ across the eight cities. The charter school costeffectiveness advantage ranges from 2 percent in Houston to 67 percent in the nation's capital (figure 2). Seven of the eight cities have public charter school cost-effectiveness advantages exceeding 10 percent and six of these are above 20 percent.

\author{
The student-weighted public \\ charter school advantage \\ of 3.99 points per $\$ 1,000$ \\ represents a cost-effectiveness \\ benefit of 35 percent.
}

\section{The charter school cost-effectiveness advantage ranges from 2 percent in Houston to 67 percent in the nation's capital.}


Figure 2: Reading Cost-Effectiveness Advantage for Public Charter Schools in Percentage Terms, by City

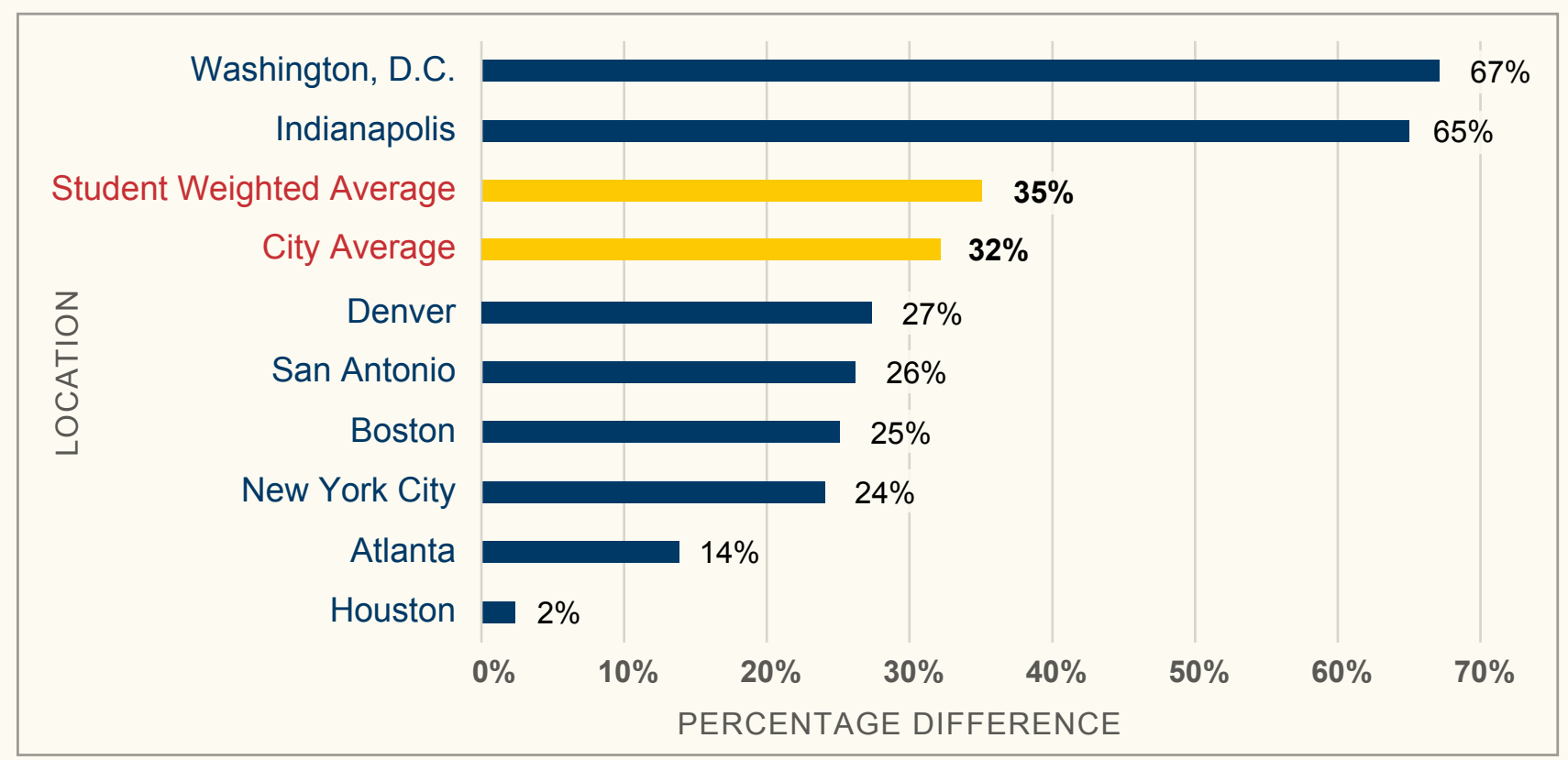

The charter school advantage slightly widens when we turn our attention to NAEP math scores. On average, per $\$ 1,000$ funded, the public charter school sectors in our study produce 19.21 NAEP math points compared to 14.48 points for the TPS sectors (table 2). This 4.73 point math difference is equivalent to a 33 percent cost-effectiveness advantage for public charter schools. The student-weighted average production of the public charter sector was 16.59 NAEP math points per $\$ 1,000$ compared to 12.22 for TPS. The student-weighted public charter school advantage of 4.37 points per $\$ 1,000$ represents a costeffectiveness benefit of 36 percent.

The public charter school advantage in math cost-effectiveness is 20 percent or larger in all but two locations - Atlanta and Houston (figure 3). Again, the gaps were the largest in D.C. and Indianapolis, where the charter school cost-effectiveness advantage exceeded 64 percent in both locations. Boston, New York City, and San Antonio all had charter schools producing around 25 percent higher math test scores for each $\$ 1,000$ funded.

\section{This 4.73 point math difference is equivalent to a 33 percent cost- effectiveness advantage for public charter schools.}

The public charter school advantage in math cost-effectiveness is 20 percent or larger in all but two locations - Atlanta and Houston. 
Table 2: NAEP Math Achievement Levels per Thousand Dollars Funded

\begin{tabular}{|c|c|c|c|c|c|c|c|}
\hline \multirow[b]{2}{*}{ Location } & \multicolumn{3}{|c|}{ Traditional Public Schools } & \multicolumn{3}{|c|}{ Public Charter Schools } & \multirow{2}{*}{$\begin{array}{c}\text { Difference } \\
\text { NAEP Points } \\
\text { per } \$ 1,000 \\
\text { Funded }\end{array}$} \\
\hline & $\begin{array}{l}\text { NAEP } \\
\text { Score }\end{array}$ & $\begin{array}{l}\text { Per Pupil } \\
\text { Revenue }\end{array}$ & $\begin{array}{c}\text { NAEP Points } \\
\text { per } \$ 1,000 \\
\text { Funded }\end{array}$ & $\begin{array}{l}\text { NAEP } \\
\text { Score }\end{array}$ & $\begin{array}{l}\text { Per Pupil } \\
\text { Revenue }\end{array}$ & $\begin{array}{c}\text { NAEP Points } \\
\text { per } \$ 1,000 \\
\text { Funded }\end{array}$ & \\
\hline Indianapolis & 277.90 & $\$ 14,388$ & 19.32 & 280.21 & $\$ 8,810$ & 31.81 & 12.49 \\
\hline San Antonio & 281.66 & $\$ 12,097$ & 23.28 & 280.61 & $\$ 9,629$ & 29.14 & 5.86 \\
\hline Denver & 266.78 & $\$ 14,027$ & 19.02 & 269.47 & $\$ 11,083$ & 24.31 & 5.30 \\
\hline Washington, D.C. & 263.13 & $\$ 35,261$ & 7.46 & 267.82 & $\$ 21,387$ & 12.52 & 5.06 \\
\hline Boston & 279.48 & $\$ 22,389$ & 12.48 & 290.82 & $\$ 18,475$ & 15.74 & 3.26 \\
\hline New York City & 273.44 & $\$ 26,289$ & 10.40 & 278.51 & $\$ 21,281$ & 13.09 & 2.69 \\
\hline Atlanta & 272.34 & $\$ 16,429$ & 16.58 & 272.97 & $\$ 14,490$ & 18.84 & 2.26 \\
\hline Houston & 282.11 & $\$ 10,829$ & 26.05 & 282.92 & $\$ 10,604$ & 26.68 & 0.63 \\
\hline AVERAGE & 274.61 & $\$ 18,963$ & 14.48 & 277.92 & $\$ 14,470$ & 19.21 & 4.73 \\
\hline $\begin{array}{l}\text { STUDENT-WEIGHTED } \\
\text { AVERAGE }\end{array}$ & 274.62 & $\$ 22,480$ & 12.22 & 277.27 & 16,718 & 16.59 & 4.37 \\
\hline
\end{tabular}

Note: Revenue data pertain to the 2014 Fiscal Year, which aligns with the 2013-2014 Academic Year, and are adapted from Charter School Funding: Inequity in the City, by Wolf et al., 2017, http://www.uaedreform.org/charter-school-funding-inequity-in-the-city/. NAEP achievement data are from 2015 and are adapted from http://nces.ed.gov/nationsreportcard/naepdata/dataset.aspx.

Figure 3: Math Cost-Effectiveness Advantage for Public Charter Schools, by City

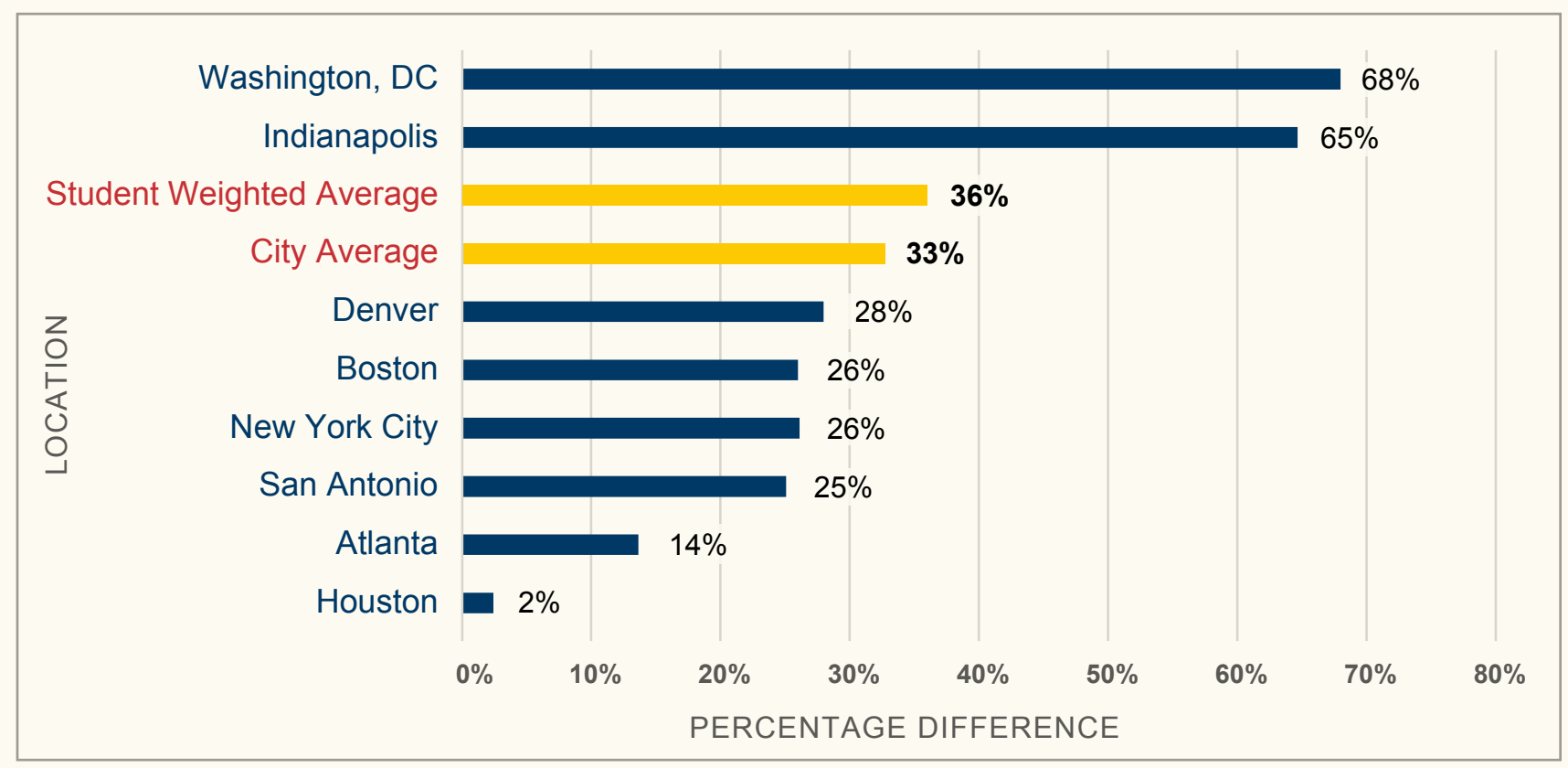




\section{Calculating ROI in Terms of Economic Returns to Education}

Return-on-investment (ROI) is:

A performance measure used to evaluate the efficiency of an investment or to compare the efficiency of a number of different investments. ROI measures the amount of return on an investment relative to the investment's cost. To calculate ROI, the benefit (or return) of an investment is divided by the cost of the investment, and the result is expressed as a percentage or a ratio. ${ }^{21}$

In our case, the ROI is the average impact each sector has on student learning gains, and the cost of the investment is the total per-pupil revenue allocated over 13 years of schooling for each sector. To monetize this measure, we convert the average learning gains produced by each public school sector to the economic return of lifetime earnings. This ROI is essentially a benefit-cost ratio, calculated as:

\section{$R O=\frac{\text { Income Returns to Investment }}{\text { Cost of Investment }}$}

The cost of investment is a straightforward calculation that captures the per-pupil revenue invested in a child's K-12 educational experience over 13 years. This can easily be calculated by multiplying the average FY 2014 per-pupil revenue for each sector by 13.
The income return to investment is the net present value of additional lifetime earnings accrued through higher cognitive ability as measured by test scores. Average learning gains for the charter and TPS sectors in each of the eight cities come from the CREDO Urban Charter School Study. CREDO researchers carefully matched students in the public charter sector with "virtual twins" in the TPS sector on previous test scores and low-income, English language learner, and special education status. ${ }^{22}$ Stanford University economist Eric Hanushek has estimated that a one standard deviation increase in cognitive ability leads to a 13 percent increase in lifetime earnings. ${ }^{23}$ Only 70 percent of gains in learning persist each year. If we multiply these two estimates together, we find the learning gains relative to the average worker in the state. By comparing the learning gains relative to the average worker in the state, we estimate the returns to the schooling investment in terms of yearly income. ${ }^{24}$ We use 2016 data from the United States

Bureau of Labor Statistics to find state-level average annual earnings and assume that current students will work for 46 years between the ages of 25 and $70 .{ }^{25}$ When calculating the net present value of lifetime earnings, we assume a one percent yearly growth in average salaries and a three percent annual discount rate. ${ }^{26}$ 
The calculation can be expressed by the following formula (see box below for specifics):

$$
\text { Lifetime Earnings in State } *[1+(\text { Sector SD }) *(0.13 / S D) *(0.70)]^{13}=\text { Lifetime Earnings in Sector }
$$

\section{$\mathrm{RO}=\frac{\text { Income Returns to Investment }}{\text { Cost of Investment }}$}

\section{Overall ROI Results}

Our return on investment calculations for each city can be located in a graph with four quadrants, depending on whether student achievement is higher for public charter schools or TPS and whether student funding is higher for charters or TPS (figure 4). In practice, the top left quadrant of the graph is all that matters to us, since all eight cities contain public charter school sectors with higher student achievement gains and lower funding than their TPS. In other words, public charter schools in these cities are outperforming their TPS despite receiving less funding per student. Boston charter
Public charter schools in these cities are outperforming their TPS despite receiving less funding per student.

schools demonstrate the highest advantage among the cities in student achievement gains compared to their TPS, an increase of 24 percent of a standard deviation. Indianapolis and Washington, D.C. reveal the largest funding gaps among the eight cities, as their public charter schools are funded almost 40 percent below the funding rate for their TPS.

\section{Figure 4: Charter School Funding and Performance}

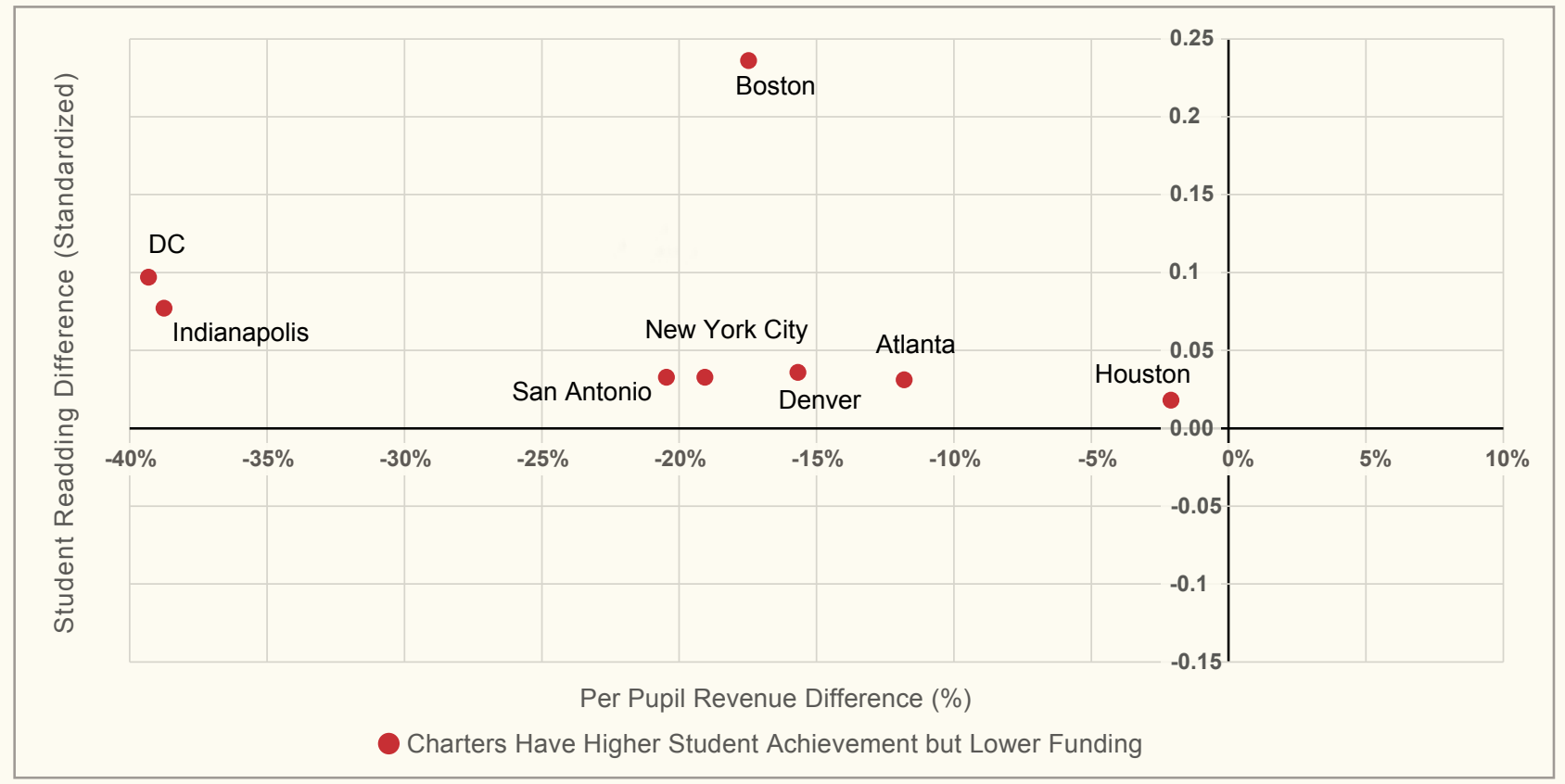

Note: Revenue data pertain to the 2014 Fiscal Year, which aligns with the 2013-2014 Academic Year, and are adapted from Charter School Funding: Inequity in the City, by Wolf et al., 2017, http://www.uaedreform.org/charter-school-funding-inequity-in-the-city/. Achievement data are standardized relative to the state overall and cover 2006-07 to 2011-12 and are provided by the Center for Research on Education Outcomes (CREDO) Urban Charter School Study: Report on 41 Regions, http://urbancharters.stanford.edu/ summary.php.

BIGGER BANG, FEWER BUCKS? THE PRODUCTIVITY OF PUBLIC CHARTER SCHOOLS IN EIGHT U.S. CITIES 
The public charter school ROI benefit is even larger than the cost-effectiveness advantage of charters. On average across the cities, each dollar invested in a child's K-12 schooling results in \$6.44 in lifetime earnings in public charter schools compared to $\$ 4.67$ in lifetime earnings in TPS, a higher return of $\$ 1.77$ per dollar in the charter versus TPS sectors. As revealed in table 3 and figure 5, averaged across the eight cities, a 13-year investment in public charters yields ROIs that are 38 percent higher than a TPS investment. The student-weighted average charter school advantage in $\mathrm{ROI}$ is $\$ 2.09$ or 53 percent. The charter school ROI advantage exceeds 20 percent in six locations, ranging from 4 percent in Houston to 85 percent in the nation's capital. Notably, public charter school ROI advantages exceed 60 percent in Boston, Indianapolis, and Washington, D.C.

\section{A 13-year investment in public charters yields ROIs that are 38 percent higher than a TPS investment.}

\section{Calculating Relative ROI Using the Economic Returns to Education}

Again, the ROI for each city and sector can be calculated as:

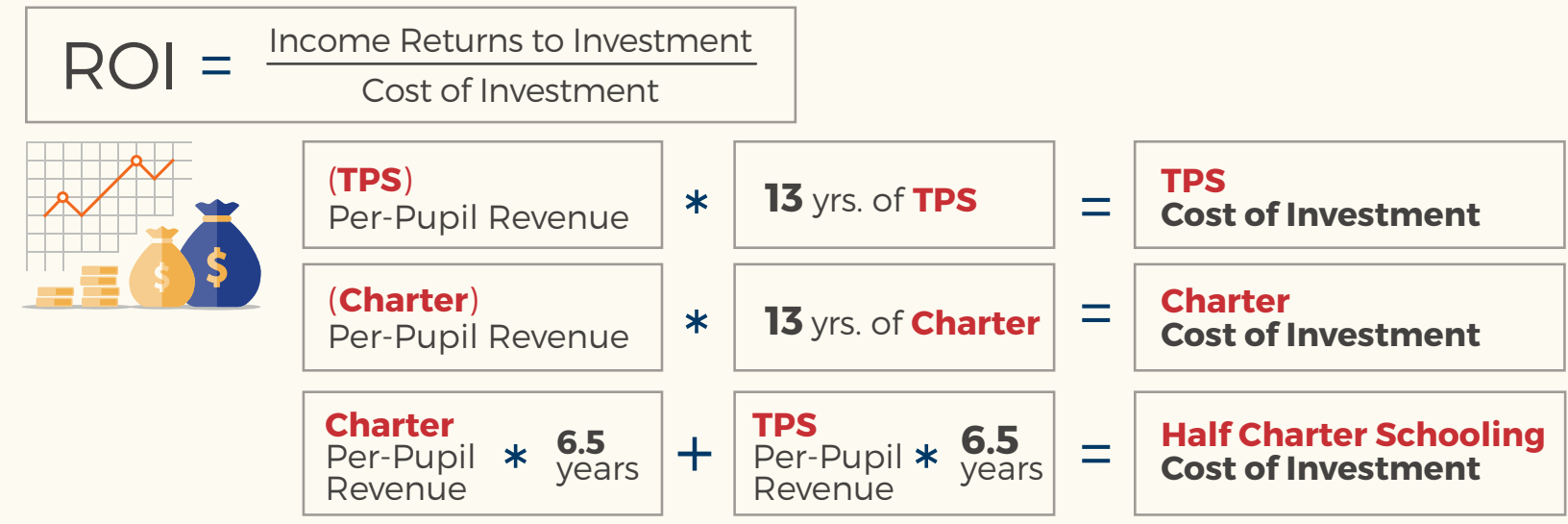

\begin{tabular}{|c|c|c|c|c|}
\hline $\begin{array}{l}\text { Average lifetime } \\
\text { earnings for workers } \\
\text { in a given state }\end{array}$ & + & $\begin{array}{l}\text { changes in lifetime } \\
\text { earnings accrued from } \\
\text { learning gains in TPS }\end{array}$ & $=$ & $\begin{array}{l}\text { Income Return to Investment } \\
\text { for TPS Students }\end{array}$ \\
\hline $\begin{array}{l}\text { Average lifetime } \\
\text { earnings for workers } \\
\text { in a given state }\end{array}$ & + & $\begin{array}{l}\text { changes in lifetime } \\
\text { earnings accrued from } \\
\text { learning gains in Charters }\end{array}$ & $=$ & $\begin{array}{l}\text { Income Return to Investment } \\
\text { for Charter Students }\end{array}$ \\
\hline
\end{tabular}

\section{Example Computation: Atlanta}

We again turn to Atlanta for an example of how we computed the charter school ROI compared to the TPS ROI. The per pupil-revenue is $\$ 16,429$ in TPS and $\$ 14,490$ for public charter schools, so a 13 year investment would equal \$213,577 in TPS and \$188,369 in charters. The average lifetime 
earnings for a worker in the state of Georgia is $\$ 1,158,067 .{ }^{27}$ Since the expected Atlanta TPS achievement effects are 14.5 percent of a standard deviation less than the Georgia state average, and 70 percent of learning impacts disappear from one year to the next, the expected lifetime earnings for a student spending 13 years in a TPS in Atlanta is $\$ 974,409$. Dividing this benefit by the cost of investment yields an ROI of $\$ 4.56$ for each dollar invested in TPS in Atlanta. Since the expected Atlanta public charter school achievement effects are 11.4 percent of a standard deviation lower than the Georgia state average, the expected lifetime earnings for a student attending a public charter school for 13 years in Atlanta is $\$ 1,011,249$. Dividing this benefit by the cost of investment yields an ROI of $\$ 5.37$ for each dollar invested in public charters in Atlanta. The charter school ROI of $\$ 5.37$ compared to the TPS ROI of $\$ 4.56$ yields an 18 percent ROI advantage favoring public charter schools in Atlanta.

Further, if a student in Atlanta experiences half of their K-12 education (6.5 years) in TPS and the other half in public charters, the taxpayer $\mathrm{ROI}$ is $\$ 4.94$, still around 8 percent higher than the ROI for a full 13-year K-12 educational investment in TPS.

ROI = Income Returns to Investment / Cost of Investment

Cost of Investment $=$ Per-Pupil Revenue $\left(\right.$ TPS) ${ }^{*} 13$ years

\section{In TPS Full Time:}

Lifetime earnings amount:

$\$ 1,158,067 *[1-(0.145 \mathrm{SD}) *(0.13 / \mathrm{SD}) *(0.70))]^{13}=\mathbf{\$ 9 7 4 , 4 0 9}$
$\$ 16,429 * 13$ years $=\mathbf{\$ 2 1 3 , 5 7 2}$ ROI for TPS: $\$ 974,409 / \$ 213,572=\mathbf{\$ 4 . 5 6}$
In Charter Full Time:

Lifetime earnings amount:

$\$ 1,158,067 *[1-(0.114 \mathrm{SD}) *(0.13 / \mathrm{SD}) *(0.70))]^{13}=\mathbf{\$ 1 , 0 1 1 , 2 4 9}$
$\$ 14,490 * 13$ years $=\$ \mathbf{1 8 8 , 3 6 9}$ ROI for Charter:

$\$ 1,011,249 / \$ 188,369=\$ 5.37$
In Charter Half Time:

Lifetime earnings amount:

$\$ 1,158,067 *[1-(0.145 \mathrm{SD}) *(0.13 / \mathrm{SD}) *(0.70))]^{6.5}+$ $\$ 1,158,067 *[1-(0.114 \mathrm{SD}) *(0.13 / \mathrm{SD}) *(0.70))]^{6.5}=\mathbf{\$ 9 9 2 , 6 5 8}$
$(\$ 14,490 * 6.5$ years $)+(\$ 16,429 * 6.5$ years $)=\mathbf{\$ 2 0 0 , 9 7 0}$

ROI for Half in Each: $\$ 992,658 / \$ 200,970=\mathbf{\$ 4 . 9 4}$

Moreover, an investment in students spending half of their time in each sector yields an overall ROI benefit of $\$ 5.40$ for each invested dollar, a 16 percent advantage relative to a full-time (13 year) $\mathrm{K}$ - 12 experience in TPS or 29 percent if student-weighted. ${ }^{28}$ As shown in the last column of table 3, and figure 6 , these benefits in higher ROI from charter schooling range from 2 percent in Houston to 32 percent in Washington, D.C. 
Table 3: ROI Comparisons between Charter and Traditional Public Schools in the Cities

\begin{tabular}{|l|c|c|c|c|}
\cline { 2 - 5 } \multicolumn{1}{c|}{} & \multicolumn{2}{c|}{ Charter 13 Years } & \multicolumn{2}{c|}{ Charter 6.5 Years } \\
\hline Wocation & $\begin{array}{c}\text { ROI Difference } \\
\text { (Charter - TPS) }\end{array}$ & $\begin{array}{c}\text { ROI Difference } \\
\text { (Percent) }\end{array}$ & $\begin{array}{c}\text { ROI Difference } \\
\text { (Charter - TPS) }\end{array}$ & $\begin{array}{c}\text { ROI Difference } \\
\text { (Percent) }\end{array}$ \\
\hline Washington, D.C. & $\$ 3.83$ & 85 & $\$ 1.44$ & 32 \\
\hline Indianapolis & $\$ 3.27$ & 79 & $\$ 1.24$ & 30 \\
\hline Boston & $\$ 1.59$ & 62 & $\$ 0.68$ & 14 \\
\hline San Antonio & $\$ 1.16$ & 32 & $\$ 0.51$ & 13 \\
\hline New York City & $\$ 2.28$ & 30 & $\$ 1.01$ & 13 \\
\hline Atlanta & $\$ 0.87$ & 29 & $\$ 0.39$ & 27 \\
\hline Houston & $\$ 0.81$ & 18 & $\$ 0.38$ & 29 \\
\hline CITY AVERAGE & $\$ 0.33$ & 4 & $\$ 0.72$ & 29 \\
\hline STUDENT-WEIGHTED & $\$ 1.77$ & 38 & $\$ 1.15$ & \\
\hline AVERAGE & $\$ 2.09$ & 53 & & 2 \\
\hline
\end{tabular}

Figure 5: ROI for Charter Schools Relative to TPS (13 Years in Charter)

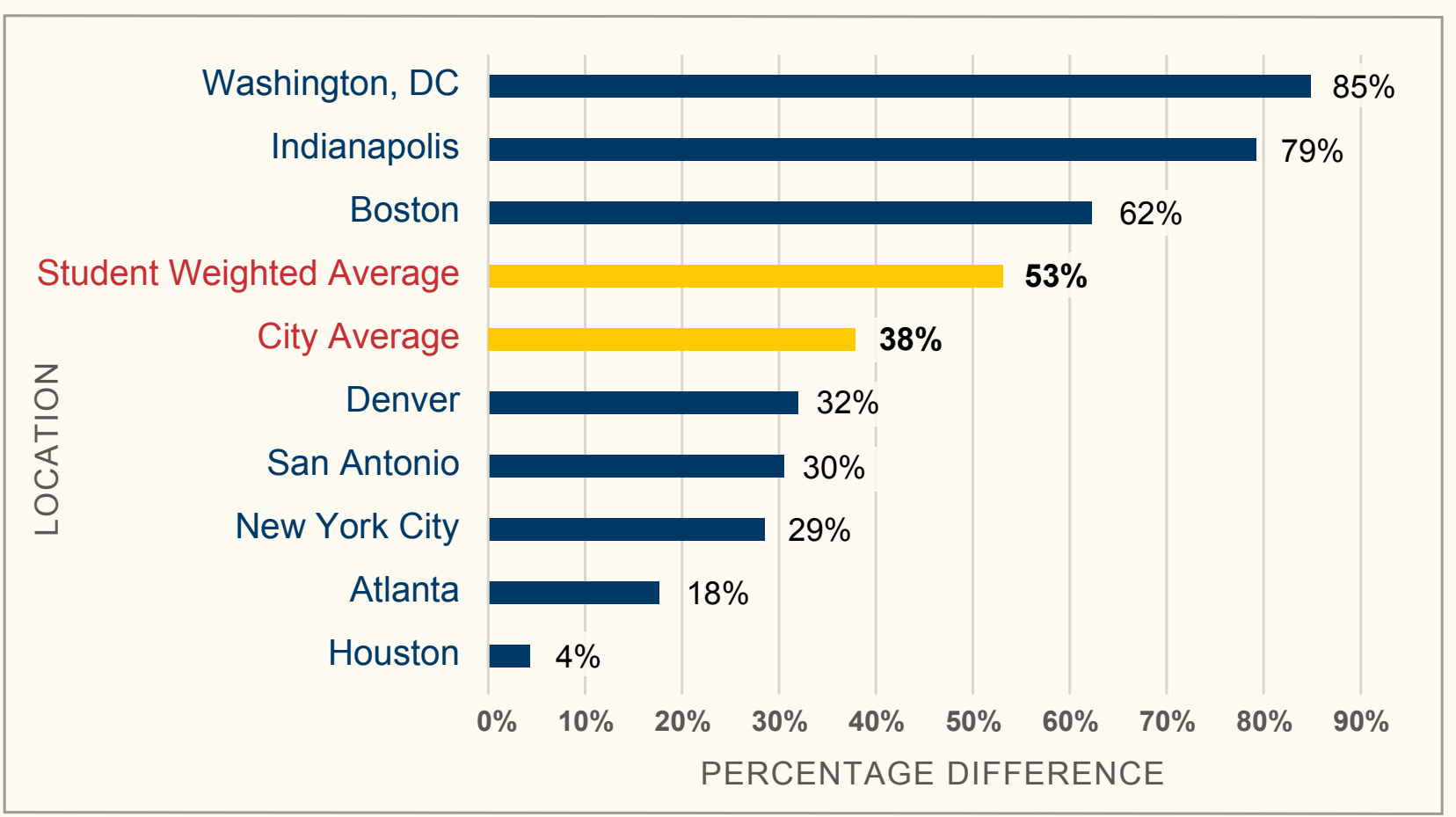


Figure 6: ROI for Charter Schools Relative to TPS (6.5 Years in Charter)

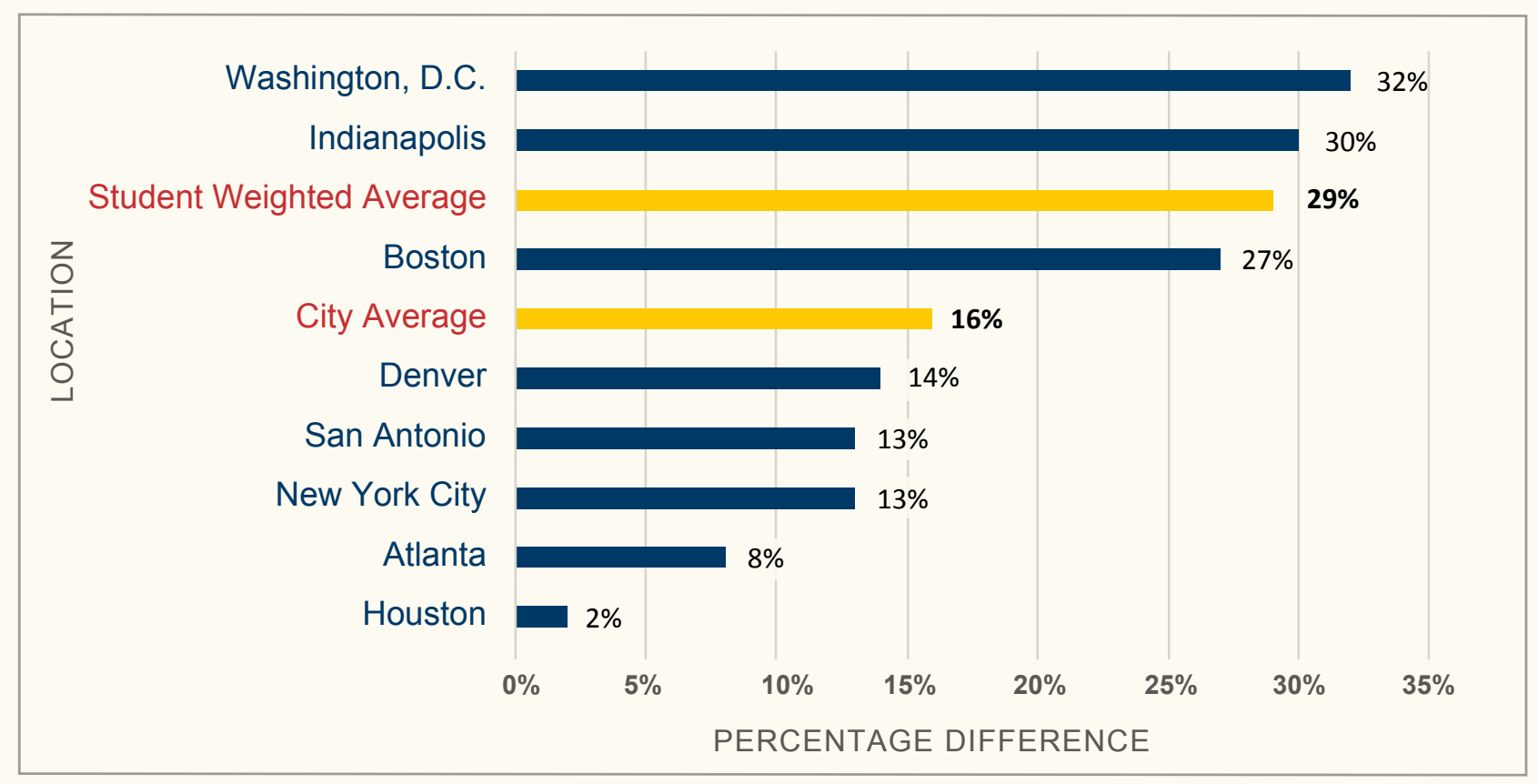

\section{Conclusion and Policy Implications}

This report further supports the existing evidence that public charter schools result in a bigger bang for fewer bucks than traditional public schools.

Our evidence indicates that charter schools, on average, yield a more efficient allocation of educational resources than does the traditional way of delivering public education through geographically defined school districts. Since educational resources are limited, charter schools look to be an especially attractive vehicle for delivering education to students more productively.

Our study has limitations. It is merely descriptive, presenting the relationships between school revenue and student outcomes as they were observed. However, the cost-effectiveness and $\mathrm{ROI}$ analyses are rigorous, as they both use CREDO results based on a quasi-experimental methodology that eliminates many observable differences in student background characteristics across the public charter and TPS sectors. In addition, our productivity results are similar - both indicating large public charter school advantages - whether estimating cost-effectiveness or ROI.

The situation in Houston requires some explanation. Houston public charter schools had the smallest advantage in productivity relative to their TPS among the eight charter sectors in our study. That does not mean, however, that Houston charters are laggards in either performance or 
productivity. The public charter school sector in Houston was third highest among the urban charter sectors in cost-effectiveness for both reading and math, exceeded only by the charter sectors in Indianapolis and San Antonio. The traditional public school sector in Houston, however, was the most productive TPS in our study. Thus, the small size of the productivity advantage of Houston charters relative to Houston TPS is largely due to both public school sectors in Houston being highly and almost equally productive.

Our findings only pertain to the eight cities included in our analyses. Those cities, however, represent the diversity of American urban areas with public charter school sectors. Our sample includes both the largest city in the U.S., New York, and a relatively small one, Atlanta. It includes cities in the north (Boston \& Indianapolis), south (Atlanta, Houston \& San Antonio), east (Boston \& Washington, D.C.), and west (Denver). The public charter school sectors in all eight of these U.S. cities are more cost-effective and deliver a higher return-oninvestment than their respective traditional public school sectors. In these important urban environments, there is a clear productivity advantage for public charter schools. 


\section{Appendix A}

\section{Methodology for Revenue Data that Informed the Study}

\section{Location Selection}

The team selected 15 metropolitan areas for the revenue analysis that contributed to this return on investment (ROI) study, ${ }^{29}$ based on one of two criteria: the concentration of charter schools within an area or the potential for charter school growth there. Locations represent selected cities or counties used as an analysis domain for aggregating district data and geographically and demographically similar charter school data for comparative purposes. The objective of our location selection is to match district students with charter students by educational setting and student need. Locations are used as a proxy for urban/metropolitan settings. They can include a single district or multiple districts, and include geographically related multiple charter schools. The revenue study provided district and charter revenue totals and funding disparity amounts

Table A1: Cities Included in and Excluded from the Productivity Analyses

\begin{tabular}{|l|c|l|}
\hline \multicolumn{1}{|c|}{ City } & $\begin{array}{c}\text { Included in NAEP } \\
\text { ROI Analysis }\end{array}$ & Reason for Exclusion from Analysis \\
\hline Houston & Yes & \\
\hline Atlanta & Yes & \\
\hline Boston & Yes & \\
\hline New York City & Yes & \\
\hline San Antonio & Yes & \\
\hline Denver & Yes & NAEP Achievement Data Not Available \\
\hline Indianapolis & Yes & NAEP Achievement Data Not Available \\
\hline Washington, D.C. & No & NAEP Achievement Data Not Available \\
\hline Tulsa & No & NAEP Achievement Data Not Available \\
\hline Little Rock & No & NAEP Achievement Data Not Available \\
\hline Shelby & No & NAEP Achievement Data Not Available \\
\hline Los Angeles & No & Outlier \\
\hline Oakland & No & \\
\hline Camden & & \\
\hline New Orleans & No & \\
\hline
\end{tabular}

for each location. As shown in the table below, our productivity analysis was limited to eight locations because NAEP scores were not available for six locations and one location was an outlier.

\section{Fiscal Year}

We gathered publicly available revenue data for the 2013-14 fiscal year (FY14). Because states differ in the fiscal year used for their public schools, we attempted to select the fiscal year that most closely matched the 2013-14 school year. We refer to that year throughout this report as "FY 2014."

\section{Data Gathering}

Source records were acquired directly from official state department of education records, and from independently audited financial statements when a state does not collect financial data. For New York City, we used detailed expenditure data from the New York City Education Department due to the greater level of detail available. We used the most reliable, most detailed, official records available in all cases. The same data and analysis standards for three previous revenue studies were applied for each location in the study. ${ }^{30}$

Revenues and expenditures were collected from many sources, from state and federal agencies where these data are kept, as well as from audits. After the FY14 school year concluded, the 
team waited 18 months to begin researching this project to allow state departments of education and charter schools time to produce and submit all of their official financial records, Annual Financial Reports, independent audits, enrollment statistics, and other data. The methodology matches a state's Department of Education's (DOE) records of school district revenues to the same fiscal year of data drawn from independent audits for the charter schools. Because all data analyzed for districts and charter schools are as of the same date, FY14, all data are properly matched based on reporting time period.

The analytic team did not rely upon finance data or demographic data collected by Federal agencies, except in very rare cases where the data are not available from state and local sources. Data sourced from Federal agencies have gone through extensive aggregation and reporting processes that tend to be aggregated to the point where there is insufficient specificity to be useful for our analysis, and where we have seen reporting errors when checked against original state sources.

New Orleans is excluded from our recent set of reports, including this productivity analysis. State funding and accounting for charter schools since Hurricane Katrina has been unusual in the Crescent City and not representative of patterns or practices in other places.

\section{Data from Various Unique State Sources, Analyzed into Comparative Datasets}

In each state that was home to one of the metropolitan areas in our analysis, we encountered a maze of web sites, reports, audits, and other information that, while extremely challenging to piece together, ultimately provided the best sources of primary data for understanding and analysis of funding levels and comparisons. By using each state's individual accounting system, we were able to isolate revenue streams for inclusion or exclusion to accommodate our consistent methodology and to make valid comparisons across school sectors and locations.

We began our research on state web sites, searching for financial data reported by local, state, federal, and other revenue categories. Though many states provided some form of revenue data, often the data existed only for school districts (not charters), or the data did not conform to the classifications used in other states. In those cases, we used additional data sources to develop conforming revenue figures. In instances where the state did not collect charter school revenue data, we used independent audits of financial data and sometimes federal Form 990.

We gathered enrollment data from state education department web sites. We also obtained funding formula guidelines for both districts and charters for FY 2013-14.

\section{Analysis of Revenues, Inclusions and Exclusions, Demographic Context}

Productivity calculations, such as these, are informed by the revenues received by organizations, not their expenditures. Our mission was to examine how charter schools were treated in state public finance systems, so we focused on how much money schools received as a social investment. We looked for the following data and supporting detail:

- Revenues: We included all revenues received by districts and public charter schools. Our goal was to determine the total amount of revenue received to run all facets of a school system, regardless of source. This analysis includes revenues and enrollments related to Adult Education and Pre-K. Also included are charter school contributions for the purpose 
of building schools (or other capital items), and similarly charter (if any) and district bond and loan proceeds for the purpose of building schools, excluding proceeds resulting from restructuring of debt. For charter schools, we included one-time revenues associated with starting the school, such as the federal Public Charter School Program and, in some cases, state and private grants. Fund transfers were not considered revenue items, and were not included in the analysis.

Arguably, one-time revenues could have been excluded since they are not part of a charter school's recurring revenues. However, they are a notable part of the funding story for the charter sector; when considering how much money is provided to run charter schools, these revenues cannot be and were not ignored. Furthermore, we also included onetime grants of various kinds to districts.

- Funds initially received by traditional public schools that were passed along to charters usually were flagged as pass-through funds in the documentation we used to determine charter school revenue. In some cases we were able to identify additional cases of TPS providing services to charter students, usually involving special education, through examining expenditure data. In all cases where we were able to determine that traditional public school (TPS) funds either passed through to charters or were spent on charter school students we counted that as charter school revenue and not TPS revenue. For example, the New York City school district made \$186 million in in-kind expenditures supporting the charter schools in the city in FY14. We reduced the district's revenue by $\$ 186$ million and increased the charter sector total by the same amount, as that revenue supported charter students. For further detail on how we handled in-kind support for charter schools, and the fascinating case of charter school funding in the Big Apple, see our recent case study of New York City. ${ }^{31}$

- Enrollment: Where multiple forms of enrollment data were available, we used the figures related to the official fall count day. Depending on a state's particular method of reporting enrollment, the official count could be either Average Daily Attendance (ADA) or Average Daily Membership (ADM).

- Exclusion of Revenue: The only revenue item we excluded from our analysis was funds resulting from the restructuring of debt, as those are not "new revenues" but merely a repackaging of existing assets and obligations.

- Selection of Schools: All charter schools in each locality were included in this study with the exception of schools for which we could not obtain valid revenue and enrollment data. If we could not obtain revenue data, the enrollments for those schools were excluded from the analysis. If we could not obtain enrollment data, the revenues for that school were excluded from the analysis.

\section{Rounding}

Dollar values were rounded to the nearest dollar for each item. Percentages were rounded to the nearest whole number, which may cause apparent differences by a percentage.

\section{Tables and Charts}

If no citation accompanies a table or chart, the information therein was compiled by the research team according to the process outlined above. When we relied on the data or publications of other organizations, we provided the relevant citation. 


\section{Weighted Average Calculations}

The totals presented in each table are weighted averages based on enrollments in the public school sectors of each city. We generated them by taking the total student enrollment in a specific city for the 2014 Fiscal Year (2013-14 Academic Year) in their TPS sector and dividing it by the total student enrollment in all eight cities in their TPS that year. We did the same for their public charter school sectors. To generate the student-weighted average differences we multiply each city's TPS costeffectiveness or ROI by its percent of the total enrollment for TPS in our collection of cities (table A2), take the average of those eight numbers, do the same for the charter sector, and subtract the TPS student-weighted average from the charter student-weighted average. This straightforward method automatically generates a student-weighted average that is a "true" mean for the aggregated set of cities, given their different enrollments across the cities and between the public school sectors.

Table A2: Percent of Students from Study Locations, FY14

\begin{tabular}{|l|r|r|r|r|r|}
\hline \multicolumn{1}{|c|}{ Location } & State & $\begin{array}{c}\text { Students } \\
\text { (TPS) }\end{array}$ & $\begin{array}{c}\text { Percent of Total } \\
\text { (TPS) }\end{array}$ & $\begin{array}{c}\text { Students } \\
\text { (Charters) }\end{array}$ & $\begin{array}{c}\text { Percent of Total } \\
\text { (Charter) }\end{array}$ \\
\hline Atlanta & GA & 44,896 & $3.09 \%$ & 6,129 & $3.17 \%$ \\
\hline Boston & MA & 54,300 & $3.74 \%$ & 9,246 & $4.78 \%$ \\
\hline Denver & CO & 73,459 & $5.06 \%$ & 13,843 & $7.16 \%$ \\
\hline Houston & TX & 210,716 & $14.53 \%$ & 31,025 & $16.04 \%$ \\
\hline Indianapolis & IN & 30,813 & $2.12 \%$ & 21,392 & $11.06 \%$ \\
\hline New York City & NY & 936,009 & $64.52 \%$ & 69,093 & $35.72 \%$ \\
\hline San Antonio & TX & 53,811 & $3.71 \%$ & 6,833 & $3.53 \%$ \\
\hline Washington, D.C. & DC & 46,643 & $3.22 \%$ & 35,847 & $18.53 \%$ \\
\hline TOTALS & & $\mathbf{1 , 4 5 0 , 6 4 7}$ & $\mathbf{1 0 0 . 0 0 \%}$ & $\mathbf{1 9 3 , 4 0 8}$ & $\mathbf{1 0 0 . 0 0 \%}$ \\
\hline
\end{tabular}




\section{Appendix B}

\section{Revenue Information Sources}

\section{Colorado (Denver)}

$\checkmark$ Colorado Department of Education, the School Finance Unit

District of Columbia

$\square$ District of Columbia Public Charter School Board

$\square$ District of Columbia Department of Revenue

Georgia (Atlanta)

$\square$ Georgia Department of Education, Office of Finance and Business Operations and Charter Schools Office

$\square$ Georgia Charter Schools Association

$\square$ Fulton County Schools Finance and Business

$\square$ Atlanta Public Schools Financial Services and Charter Schools Office

Indiana (Indianapolis)

$\square$ Indiana Department of Education, School Finance

Massachusetts (Boston)

$\square$ Massachusetts Department of Elementary and Secondary Education, School Finance

$\square$ Massachusetts Department of Elementary and Secondary Education, Charter Schools Office

\section{NCES}

$\square$ Massachusetts Department of Revenue, Division of Local Services

New York (New York City)

$\square$ New York State Education Department

$\square$ Audited Annual Financial Reports from school districts

Texas (Houston, San Antonio)

$\square$ Texas Education Agency, Division of School Finance, Information Analysis Division, and Division of Charter Schools

$\square$ Texas Resource Center for Charter Schools

$\square$ Houston Independent School District

$\square$ Dallas Independent School District 


\section{Research Team}

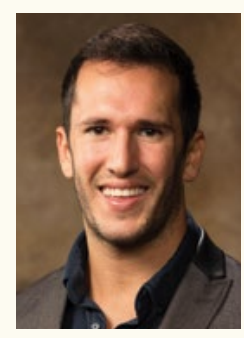

\section{Corey A. DeAngelis}

Mr. DeAngelis is a Distinguished Doctoral Fellow and Ph.D. candidate in Education Policy at the University of Arkansas in Fayetteville and a Policy Analyst at the Cato Institute's Center for Educational Freedom. His research focuses on the effects of school choice programs on student achievement and non-academic outcomes. He holds a Bachelor of Business Administration and a Master of Arts in Economics from the University of Texas at San Antonio.

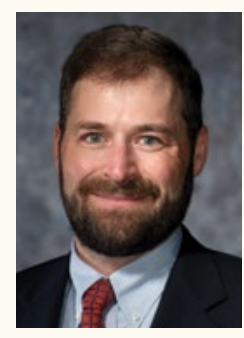

\section{Patrick J. Wolf, Ph.D.}

Dr. Wolf is a Distinguished Professor of Education Policy and 21st Century Endowed Chair in School Choice at the University of Arkansas in Fayetteville. He has authored, co-authored, or co-edited four books and over 130 journal articles, book chapters, and policy reports on school choice, civic values, public management, special education, and campaign finance. He received his Ph.D. in Political Science from Harvard University in 1995.

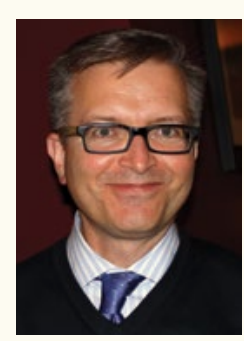

\section{Larry D. Maloney}

Mr. Maloney is president of Aspire Consulting and has investigated expenditure patterns of the nation's public schools on behalf of states and individual school districts since 1992. Mr. Maloney participated in the research team for the Fordham Institute revenue study in 2005, the Ball State University revenue study in 2010, and the University of Arkansas study in 2014. Recent projects include evaluations of revenues and expenditure patterns of eleven major metropolitan school districts and the charter schools located within their boundaries. Mr. Maloney co-authored a series of reports for the Fordham Institute on future retirement costs for three school districts, as well as conducted a school-by-school expenditure analysis for the Washington, D.C. region. He served as the evaluator for a U.S. Department of Education program designed to enhance the level of products and services provided by state charter associations. Additionally, he provided the financial analysis for the U.S. Government Accountability Office study of Title 1 expenditures and the U.S. Department of Education National Charter School Finance Study.

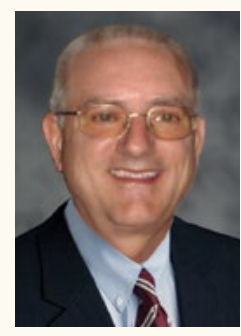

\section{Jay F. May}

Mr. May is founder of, and senior consultant for, EduAnalytics, LLC, a consulting practice focused on hands-on data-based initiatives to improve student performance. Mr. May's client work includes developing technology infrastructure for various aspects of student performance management - student information systems, instructional data management systems, assessment results delivery and analysis frameworks. Mr. May, a CPA, has expertise in K-12 education finances and provides research, consulting, and analysis for various aspects of funding equity and allocation. He is a co-inventor of In $\$$ ite ${ }^{\circ}$ - the Finance Analysis Model for Education $₫$ - a patented software tool for school-level and district-level expenditure analysis. 


\section{Endnotes}

1 National Center for Education Statistics, Table 236.10.

2 Andrews, L. (2018, January 26), The pension crisis is starting to hit home: School choice might be the only answer, National Review. Aldeman, C. (2018, January 12), Thanks to rising benefit costs, San Diego needs your help cutting its school budget, Teacher Pensions Blog.

3 National Center for Education Statistics, Public Charter School Enrollment.

4 Rossi, P. H., Lipsey, M. W., \& Freeman, H. E. (2003), Evaluation: A systematic approach, Sage publications.

5 Return On Investment - ROI.

6 Emma, C., Suro, R., Columbus, E., Akers, M. A., \& Greenfield, J. (2016, September 08). Trump unveils \$20B school choice proposal, Politico.

7 Layton, L. (2013, June 25). Charters not outperforming nation's traditional public schools, report says, Washington Post.

8 Foreman, L., Anderson, K.P., Ritter, G., Wolf, P.J. (2017), Using "broken lotteries" to check the validity of charter school evaluations using matching designs, Educational Policy. Mills, J.N. (2013). The achievement impacts of Arkansas openenrollment charter schools. Journal of Education Finance, 38(4), 320-342.

9 Cheng, A., Hitt, C., Kisida, B., \& Mills, J. N. (2017, March), "No excuses" charter schools: A meta-analysis of the experimental evidence on student achievement, Journal of School Choice 11(2), 209-238. Betts, J. R., \& Tang, Y. E. (2014), A meta-analysis of the literature on the effect of charter schools on student achievement. Working Paper. Bothell, WA: Center for Reinventing Public Education. Cremata, E., Davis, D., Dickey, K., Lawyer, K., Negassi, Y., Raymond, M. E., et al. (2013), National charter school study 2013, Center for Research on Education Outcomes, Stanford, CA: Stanford University. Zimmer, R., Gill, B., Booker, K., Lavertu, S., Sass, T. R., \& Witte, J. (2009), Charter schools in eight states: Effects on achievement, attainment, integration, and competition. Santa Monica, CA: RAND Corporation.

10 CREDO (2015), Urban Charter School Study: Report on 41 Regions, Palo Alto: Stanford University.

11 Batdorff, M., Finn, C.E., Hassel, B., Maloney, L., Osberg, E., Speakman, S., Terrell, M.G. (2005), Charter school funding: Inequity's next frontier, Washington, DC: Thomas B. Fordham Institute. Batdorff, M., Maloney, L., May, J., Doyle, D., \& Hassel, B. (2010), Charter school funding: Inequity persists, Ball State University. Batdorff, M., Maloney, L., May, J. F., Speakman, S. T., Wolf, P. J., \& Cheng, A. (2014), Charter school funding: Inequity expands, School Choice Demonstration Project, University of Arkansas.

12 Batdorff, M., Cheng, A., Maloney, L., May, J.F., \& Wolf, P.J. (2015, June), Buckets of water into the ocean: Non-public revenue in public charter and traditional public schools, School Choice Demonstration Project, University of Arkansas.

13 Wolf, P. J., Cheng, A., Batdorff, M., Maloney, L., May, J., \& Speakman, S. (2014), The productivity of public charter schools, School Choice Demonstration Project, University of Arkansas.

14 Wolf, P. J., Maloney, L. D., May, J. F., \& DeAngelis, C. A. (2017), Charter school funding: Inequity in the city, School Choice Demonstration Project, University of Arkansas.

15 We use NAEP scores from the following year since it is the closest year of data available to the 2014 revenue data. In addition, one might expect that an investment in 2014 would translate to student outcomes in the next year.

16 Johnson, R.C., \& Jackson, K. (2017), Reducing inequality through dynamic complementarity: Evidence from Head Start and public school spending. Working Paper w23489. Cambridge, MA: National Bureau of Economic Research. Hanushek, E. A. (1996), School resources and student performance, in G. Burtless (ed.), Does Money Matter? The Effect of School Resources on Student Achievement and Adult Success, Washington, DC: Brookings.

17 The state education agency for D.C. pays for some Washington students to be educated outside of the District, which is why the performance level within D.C. is not exactly equal to the "statewide" average.

18 CREDO (2015), Urban Charter School Study: Report on 41 Regions, Palo Alto: Stanford University. 
19 Wolf, P. J., Maloney, L. D., May, J. F., \& DeAngelis, C. A. (2017), Charter School Funding: Inequity in the City, School Choice Demonstration Project, University of Arkansas.

20 Rossi, P. H., Lipsey, M. W., \& Freeman, H. E. (2003), Evaluation: A systematic approach, Sage publications.

21 Return On Investment - ROI.

22 CREDO (2015), Urban Charter School Study: Report on 41 Regions, Palo Alto: Stanford University.

23 Hanushek, E. A. (2011), The economic value of higher teacher quality, Economics of Education Review, 30(3), 466-479.

24 We use learning gains for each city and sector, relative to the state, produced by CREDO (2015), Urban Charter School Study: Report on 41 Regions, Palo Alto: Stanford University.

25 United States Bureau of Labor Statistics, Occupational Employment Statistics, May 2016.

26 Hanushek, E. A. (2011), The economic value of higher teacher quality, Economics of Education Review, 30(3), 466479. See also Wolf, P. J., Cheng, A., Batdorff, M., Maloney, L., May, J., \& Speakman, S. (2014), The productivity of public charter schools, School Choice Demonstration Project, University of Arkansas.

27 Calculated from data in United States Bureau of Labor Statistics, Occupational Employment Statistics, May 2016.

28 The numerator for the calculation of ROI for students who spend 6.5 years in charters, measuring the benefits they receive from doing so, is exactly half of the numerator for students who spend all 13 years in charters. The denominator, however, is larger for students who spend 6.5 years in charters compared to those who spend 13 years in charters because spending on them is higher during the 6.5 years they are in TPS. As a result, the ROI for spending 6.5 years in a public charter school is less than half the ROI for spending 13 years in a charter.

29 Wolf, P.J., Maloney, L.D., May, J.F., \& DeAngelis, C.A. (2017, May), Charter school funding: Inequity in the city, School Choice Demonstration Project, University of Arkansas, Fayetteville, AR.

30 Batdorff, M., Maloney, L., May, J., Speakman, S., Wolf, P.J., \& Cheng, A. (2014), Charter school funding: Inequity expands, School Choice Demonstration Project, University of Arkansas, Fayetteville, AR. Batdorff, M., Maloney, L., May, J., Doyle, D., \& Hassel, B. (2010), Charter school funding: Inequity persists, Muncie, IN: Ball State University. Batdorff, M., Finn, C.E., Hassel, B., Maloney, L., Osberg, E., Speakman, S., Terrell, M.G. (2005), Charter school funding: Inequity's next frontier, Washington, DC: Thomas B. Fordham Institute.

31 Maloney, L.D., \& Wolf, P.J. (2017, August), Charter school funding: Inequity in New York City, School Choice Demonstration Project, University of Arkansas, Fayetteville, AR. 